\title{
Phylloplane Mycoflora of Colocasia at Different Growth Stages and their Antagonistic Effect on Colocasia Leaf Blight Pathogen in Vitro
}

\author{
P. Chakruno ${ }^{1 *}$ and S. Banik ${ }^{2}$
}

\begin{abstract}
Dept. of Plant Pathology, School of Agricultural Sciences and Rural Development (SASRD), Nagaland University (NU),
\end{abstract} Medziphema Campus, Nagaland (797 106), India

\section{Article History}

Manuscript No. AR989

Received in $9^{\text {th }}$ October, 2014

Received in revised form $20^{\text {th }}$ July, 2015

Accepted in final form $5^{\text {th }}$ August, 2015

\section{Correspondence to}

*E-mail: pezangulie@gmail.com

\section{Keywords}

Phylloplane mycoflora, leaf washing method, Phytophthora colocasiae

\begin{abstract}
The phylloplane mycoflora study of colocasia at different growth stages resulted in isolation of an oomycete Phytophthora colocasiae and seven (7) fungal species viz., Cladosporium herbarum, Penicillium citrinum, Aspergillus niger isolate 1, Aspergillus niger isolate 2, Penicillium spp., Mucor hiemalis and Penicillium oxalicum. Phytophthora colocasiae, the leaf blight pathogen of colocasia and Penicillium citrinum were observed predominant throughout the growing season. Leaf washing method was followed for isolating phylloplane fungi from colocasia leaf using Martin's Rose Bengal Agar as the cultivation media. Phytophthora colocasiae was observed with the highest mean number of colonies (26.60) during all the observations at different plant ages followed by P. citrinum (9.47), C. herbarum (3.27), M. hiemalis (0.47), A. niger isolate $1(0.40), A$. niger isolate $2(0.13)$ and the lowest was observed for Penicillium spp. (0.07). However marked fluctuations were observed in the population of mycoflora on the leaf surface of colocasia with the days of interval which may be correlated to rainfall that was observed during the course of the investigation. Phylloplane fungal isolates were test against Phytophthora colocasiae the leaf blight pathogen of colocasia for their antagonistic properties using dual culture method. Mucor hiemalis (50.57) was found to have fast growth and over grow the pathogen colony completely five days after inoculation, where as Cladosporium herbarum (8.37) was observed to record the lowest inhibition of the leaf blight pathogen.
\end{abstract}

\section{Introduction}

Colocasia are herbaceous plants up to $2 \mathrm{~m}$ tall and have underground corms. The leaves are large with long petiole clasping at the base. In Nagaland, colocasia occupies fifth position in terms of area under cultivation. Colocasia was cultivated in an area of 5100 ha with the total production of $48490 \mathrm{mt}$ (Statistical Handbook of Nagaland, 2011). The crop, in Nagaland is cultivated primarily under rain-fed conditions and in 'jhum' fields either as mono or mixed-crop with no or least amount of chemical inputs. The vegetative growth period of the crop coincides with rainy season or the monsoon period; the crop suffers heavily from Phytophthora blight disease caused by Phytophthora colocasiae Raciborski.

In recent times, the potential of phylloplane microflora in the biological control of foliar plant pathogens has become focal point of the research investigation in various crops. The term phylloplane is known to be the habitat on the leaf surface of a diverse group of microorganisms ranging from saprophytes to biotrophs (fungi, bacteria, actinomycetes etc.) whose population is dynamic being in a continuous state of interaction among them. Their interaction may have a stimulatory or inhibitory or sometimes no effect on the pathogenic microorganisms which are also present on the leaf surface at least for sometime before invading the host. Filamentous fungi are considered transient inhabitants of leaf surfaces, being present predominantly as spores, whereas rapidly sporulating species and yeasts colonize this habitat more actively. Both biotic and abiotic factors have direct and indirect effect on the phylloplane microflora. The number of phylloplane mycoflora increases with leaf age of guava plants (Pandey and Dwivedi, 1984). Similarly, in case of muskmelon and bottle gourd the populations of phyllosphere fungi were observed minimum on young leaves and maximum on old leaves (Singh, 1995). At different growth stages of Pinus taeda L. the newly expanded leaves were sparsely colonized by fungi, and at senescence both leaf surfaces had extensive hyphal growth and a greater internal colonization by phylloplane fungi (Venedikian and Godeas, 1996). Research 
into the characteristics of microbial life in the phylloplane is of great commercial importance to field of the agriculture. Understanding the survival of plant disease-causing fungi on the leaf surface is vital for developing new ways to control their spread and disease causing abilities. Phytophthora leaf blight of colocasia caused by Phytophthora colocasiae being the most common foliar disease of colocasia in Nagaland and considering the importance of colocasia and craving for nonchemical methods for plant disease management, a need has been felt to explore the diversity and potential of phylloplane mycoflora in managing the Phytophthora blight.

\section{Materials and Methods}

The experiments were conducted in the Department of Plant Pathology, SASRD, Nagaland University, Medziphema Campus, during the year 2012-2013 following Randomized Block Design. Colocasia cultivar Balsan, obtained from Medziphema Town, Dimapur, Nagaland was used for the experiment. The tubers were planted in soil at a depth of $8 \mathrm{~cm}$, maintaining a distance of $60 \mathrm{~cm}$ row to row and $40 \mathrm{~cm}$ plant to plant. Five leaves from the basal part of the plant (Bainbridge and Dickinson, 1972) were randomly collected in polythene bags from each replication and taken to the laboratory to carry out the required isolation procedures for estimating fungal population using leaf washing method. Isolation procedures were carried out from colocasia plants of 60 DAP stage and continued till 180 DAP stage with 30 days of interval. The isolated phylloplane fungal species were studied for their antagonistic effect against Phytophthora colocasiae using dual culture technique.

\subsection{Isolation and identification of phylloplane mycoflora}

All the isolation techniques carried out in this experiment were performed in an aseptic environment inside the laminar air flow chamber. Inside the laminar air flow chamber the leaf samples were cut into forty leaf bits of $5.0 \times 5.0 \mathrm{~mm}^{2}$ size and were transferred into a $250 \mathrm{ml}$ sterilized conical flask containing $100 \mathrm{ml}$ of sterile distilled water. The flask was thoroughly shaken for twenty minutes so that all the fungal propagules present on the leaf surface would be washed into the water. 1 $\mathrm{ml}$ of leaf washing was then transferred into a sterilized Petridish containing Martins agar medium (Mishra and Tewari, 1969 ) with the following composition; sterilized distilled water $1000 \mathrm{ml}$, agar agar $20 \mathrm{~g}, \mathrm{KH}_{2} \mathrm{PO}_{4} 1.0 \mathrm{~g}, \mathrm{MgSO}_{4} 0.5 \mathrm{~g}$, peptone $5 \mathrm{~g}$, dextrose $10 \mathrm{~g}$, Rose Bengal $0.033 \mathrm{~g}$, streptomycin 0.033 g. Three Martin's agar plates were inoculated and maintain as replications. The inoculated plates were sealed with Petri seal and were incubated at room temperature $\left(28 \pm 1{ }^{\circ} \mathrm{C}\right)$. Observation was recorded on type of fungal species, colour and number of colonies of each fungal species 2-7 days after inoculation. The fungal colonies thus obtained were further purified and maintained in PDA (Potato Dextrose Agardistilled water $1000 \mathrm{ml}$, potato $200 \mathrm{~g}$, dextrose $20 \mathrm{~g}$, agar agar $20 \mathrm{~g}$ ) slants. The typical identifying characters of each of the phylloplane mycoflora were photographed using a digital microscope. The cultural morphological and photographic descriptions, thus obtained were compared with description given in "Handbook of Soil Fungi" (A. Nagamani, I.K. Kunwar and C. Manoharachary) for identification. Further identification of all the phylloplane fungi isolated in this investigation was also made by ITCC (Indian Type Cultural Collection) Centre, Division of Plant Pathology IARI, New Delhi-110012.

\subsection{Antagonistic effect of phylloplane fungal isolates against} Phytophthora colocasiae Racib. in vitro

All the seven phylloplane fungal species viz., Cladosporium herbarum, Penicillium citrinum, Aspergillus niger isolate 1, Aspergillus niger isolate 2, Penicillium spp., Mucor hiemalis and Penicillium oxalicum, were screened under in vitro condition by using dual culture method against Phytophthora colocasiae Racib., the causal agent of colocasia leaf blight. Culture discs of $5 \mathrm{~mm}$ diameter each of the phylloplane fungal isolates and the pathogen were corked out with the help of a sterilized cork borer from the margin of activity and transferred them to Petri plates ( $90 \mathrm{~mm}$ diameter) containing PDA with the help of an inoculating loop. The discs of the phylloplane fungal species were placed upside down at one end of the Petri plates separately alongside the mycelial disc of the pathogen, placed at the opposite end. A control having only the test pathogen was also kept for comparison. The Petri plates were then incubated at $25 \pm 1^{\circ} \mathrm{C}$. The experiment combinations for the experiment were placed in a Complete Randomized Design (CRD) and each treatment was replicated three (3) times. Radial growth of the test pathogen P. colocasiae in presence of phylloplane fungal species was recorded and the $\%$ growth inhibition of the test pathogen was calculated. Recording of the antagonist effect was done 24, 48, 72, 96 and 120 hrs after incubation. The respective inhibition was calculated as follows.

$$
\mathrm{PI}=\frac{(\mathrm{C}-\mathrm{T})}{\mathrm{C}} \times 100
$$

where, PI- \% inhibition, C-Radial growth in control, T-Radial growth in treatment.

The experimental data were analyzed statistically by applying the technique of analysis of variance, using software provided by Microsoft Excel and the significance of different sources of variance was tested by Error mean square using Snedor's 'F' test of probability at $5 \%$ level of significance.

\section{Results and Discussion}

The fungi isolated from the phylloplane of colocasia are identified as given in Table 1. The experimental data presented 
in Table 2 depicts the effect of plant age on the qualitative and quantitative composition of phylloplane mycoflora of colocasia and Table 3 presents the antagonistic effect of phylloplane fungi on the radial growth of $P$. colocasiae Racib. in vitro.

\subsection{Phylloplane mycoflora of colocasia at different growth stages}

During the entire course of this investigationone oomycete Phytophthora colocasiae and seven (7) fungal species viz., Cladosporium herbarum, Penicillium citrinum, Aspergillus niger isolate 1, Aspergillus niger isolate 2, Penicillium spp., Mucor hiemalis, and Penicillium oxalicum, were isolated at different growth stages and the datas are given in Table 2. Out of these, P. colocasiae and Penicillium citrinum were found to be most predominant during the whole investigation. The results were found significant with respect to different fungal species and all the days of interval. But there was a marked fluctuation in the micro fungal population distributed on the leaf surface at different plant ages. The highest population of phylloplane mycoflora irrespective of plant age was of Phytophthora colocasiae. It was found that the incidence of Aspergillus niger isolate 2 was found to occur only at $90 \mathrm{DAP}(0.67)$, Penicillium spp. at $90 \mathrm{DAP}(0.33)$ and Penicillium oxalicum at $180 \mathrm{DAP}$ (0.33). Incidence of Cladosporium herbarum was found not to occur at 90 and $120 \mathrm{DAP}$, Aspergillus niger isolate 1 at 90, 150 and 180 DAP and Mucor hiemalis at 60 DAP. C. herbarum was most abundant (7.00) on colocasia leaf in the mature stage viz., 150 and 180 DAP compared to early stages. The mean number of fungal species in the period of study showed an

Table 1: Phylloplane mycoflora of colocasia and their taxonomic position

\begin{tabular}{|c|c|c|c|c|}
\hline $\begin{array}{l}\text { Sl. } \\
\text { no. }\end{array}$ & $\begin{array}{l}\text { ITCC } \\
\text { Ref. no. }\end{array}$ & Fungal species & Kingdom & Class \\
\hline 1. & 9037.13 & $\begin{array}{l}\text { Phytophthora } \\
\text { colocasiae }\end{array}$ & Chromista & Oomycetes \\
\hline 2. & 9038.13 & $\begin{array}{c}\text { Cladosporium } \\
\text { herbarum }\end{array}$ & Fungi & $\begin{array}{l}\text { Dothideomy- } \\
\text { cetes }\end{array}$ \\
\hline 3. & 9039.13 & $\begin{array}{l}\text { Penicillium } \\
\text { citrinum }\end{array}$ & Fungi & Eurotiomycetes \\
\hline 4. & 9040.13 & $\begin{array}{c}\text { Aspergillus } \\
\text { niger isolate } 1\end{array}$ & Fungi & Eurotiomycetes \\
\hline 5. & 9041.13 & $\begin{array}{c}\text { Aspergillus } \\
\text { niger isolate } 2\end{array}$ & Fungi & Eurotiomycetes \\
\hline 6. & 9042.13 & $\begin{array}{l}\text { Penicillium } \\
\text { spp. }\end{array}$ & Fungi & Eurotiomycetes \\
\hline 7. & 9043.13 & $\begin{array}{l}\text { Mucor } \\
\text { hiemalis }\end{array}$ & Fungi & Zygomycetes \\
\hline 8. & 9044.13 & $\begin{array}{l}\text { Penicillium } \\
\text { oxalicum }\end{array}$ & Fungi & Eurotiomycetes \\
\hline
\end{tabular}

Table 2: Phylloplane mycoflora of colocasia at different growth stages

\begin{tabular}{|c|c|c|c|c|c|c|c|}
\hline \multirow[t]{2}{*}{$\begin{array}{l}\text { Sl. } \\
\text { no. }\end{array}$} & \multirow[t]{2}{*}{ Fungus } & \multicolumn{6}{|c|}{$\begin{array}{l}\text { Number of colonies isolated from phylloplane } \\
\text { of Colocasia }\end{array}$} \\
\hline & & $\begin{array}{c}60 \\
\text { DAP }\end{array}$ & $\begin{array}{c}90 \\
\text { DAP }\end{array}$ & $\begin{array}{c}120 \\
\text { DAP }\end{array}$ & $\begin{array}{c}150 \\
D A P\end{array}$ & $\begin{array}{c}180 \\
\text { DAP }\end{array}$ & Mean \\
\hline 1. & $\begin{array}{l}\text { Phytop- } \\
\text { hthora } \\
\text { colocasiae }\end{array}$ & $\begin{array}{l}23.33 \\
(4.88)^{*}\end{array}$ & $\begin{array}{l}33.33 \\
(5.82)\end{array}$ & $\begin{array}{l}43.33 \\
(6.62)\end{array}$ & $\begin{array}{l}29.67 \\
(5.49)\end{array}$ & $\begin{array}{c}3.33 \\
(1.96)\end{array}$ & 26.60 \\
\hline 2. & $\begin{array}{l}\text { Clados- } \\
\text { porium } \\
\text { herbarum }\end{array}$ & $\begin{array}{c}2.33 \\
(1.68)\end{array}$ & $\begin{array}{c}0.00 \\
(0.71)\end{array}$ & $\begin{array}{c}0.00 \\
(0.71)\end{array}$ & $\begin{array}{c}7.00 \\
(2.74)\end{array}$ & $\begin{array}{c}7.00 \\
(2.74)\end{array}$ & 3.27 \\
\hline 3. & $\begin{array}{l}\text { Penicillium } \\
\text { citrinum }\end{array}$ & $\begin{array}{l}7.67 \\
(2.86)\end{array}$ & $\begin{array}{l}3.67 \\
(2.04)\end{array}$ & $\begin{array}{l}16.33 \\
(4.10)\end{array}$ & $\begin{array}{c}4.33 \\
(2.20)\end{array}$ & $\begin{array}{l}15.33 \\
(3.98)\end{array}$ & 9.47 \\
\hline 4. & $\begin{array}{l}\text { Aspergillus } \\
\text { niger } \\
\text { isolate } 1\end{array}$ & $\begin{array}{l}1.33 \\
(1.35)\end{array}$ & $\begin{array}{c}0.00 \\
(0.71)\end{array}$ & $\begin{array}{c}0.67 \\
(1.08)\end{array}$ & $\begin{array}{c}0.00 \\
(0.71)\end{array}$ & $\begin{array}{c}0.00 \\
(0.71)\end{array}$ & 0.40 \\
\hline 5. & $\begin{array}{l}\text { Aspergillus } \\
\text { niger } \\
\text { isolate } 2\end{array}$ & $\begin{array}{c}0.00 \\
(0.71)\end{array}$ & $\begin{array}{c}0.67 \\
(1.08)\end{array}$ & $\begin{array}{c}0.00 \\
(0.71)\end{array}$ & $\begin{array}{c}0.00 \\
(0.71)\end{array}$ & $\begin{array}{c}0.00 \\
(0.71)\end{array}$ & 0.13 \\
\hline 6. & $\begin{array}{l}\text { Penicillium } \\
\text { spp. }\end{array}$ & $\begin{array}{c}0.00 \\
(0.71)\end{array}$ & $\begin{array}{c}0.33 \\
(0.91)\end{array}$ & $\begin{array}{c}0.00 \\
(0.71)\end{array}$ & $\begin{array}{c}0.00 \\
(0.71)\end{array}$ & $\begin{array}{c}0.00 \\
(0.71)\end{array}$ & 0.07 \\
\hline 7. & $\begin{array}{l}\text { Mucor } \\
\text { hiemalis }\end{array}$ & $\begin{array}{c}0.00 \\
(0.71)\end{array}$ & $\begin{array}{c}0.67 \\
(1.08)\end{array}$ & $\begin{array}{c}0.33 \\
(0.91)\end{array}$ & $\begin{array}{c}1.00 \\
(1.22)\end{array}$ & $\begin{array}{c}0.33 \\
(0.91)\end{array}$ & 0.47 \\
\hline 8. & $\begin{array}{l}\text { Penicillium } \\
\text { oxalicum }\end{array}$ & $\begin{array}{c}0.00 \\
(0.71)\end{array}$ & $\begin{array}{c}0.00 \\
(0.71)\end{array}$ & $\begin{array}{c}0.00 \\
(0.71)\end{array}$ & $\begin{array}{c}0.00 \\
(0.71)\end{array}$ & $\begin{array}{c}0.33 \\
(0.91)\end{array}$ & 0.07 \\
\hline \multirow{2}{*}{\multicolumn{2}{|c|}{ Mean }} & 4.33 & 4.83 & 7.58 & 5.25 & 3.29 & \\
\hline & & & MSE & & \multicolumn{3}{|c|}{$\mathrm{CD}(p=0.05)$} \\
\hline \multicolumn{2}{|c|}{ Fungus (F) } & & 11.98 & & \multicolumn{3}{|c|}{1.98} \\
\hline \multicolumn{2}{|c|}{ Treatment $(\mathrm{T})$} & & 11.98 & & \multicolumn{3}{|c|}{2.51} \\
\hline \multicolumn{2}{|c|}{$\mathrm{F} \times \mathrm{T}$} & & 11.98 & & \multicolumn{3}{|c|}{5.62} \\
\hline
\end{tabular}

DAP: Days after planting; ${ }^{*}$ Figures in the parentheses indicate square root transformed values

upward trend from 4.33 to 7.58 upto 120 DAP and thereafter it declined gradually to 3.29 at 180 DAP. It was recorded that phylloplane fungal population of Amaranthus paniculates is higher in flowering stage of the host (Pandey and Gupta, 1985). Similarly, microbial population on cowpea leaves reached maximum at the crop stage of 60 days (Jindal and Thind, 1990). It was observed that the phylloplane mycoflora did not increase with the ageing of plant as reported by Pandey and Dwivedi (1984) that the number of phylloplane mycoflora increased with plant age, instead marked fluctuations were observed in the micro fungal population on the leaf surface of colocasia with the days of interval which may be correlated to the rainfall $(120,150$ and $180 \mathrm{DAP})$ and relative humidity $(120,150$ and 180 DAP) that were observed during the course of the investigation. However in the context of colocasia disease, Pouono et al. (1996) reported that disease incidence 


\begin{tabular}{|c|c|c|c|c|c|c|c|c|c|c|c|}
\hline \multirow[t]{3}{*}{ Treatments } & \multicolumn{10}{|c|}{ Radial growth $\left(\mathrm{mm}\right.$ ) and $\%$ inhibition (PI) of Phytophthora colocasiae after hrs at $25 \pm 1{ }^{\circ} \mathrm{C}$} & \multirow[t]{3}{*}{ Mean } \\
\hline & \multicolumn{2}{|c|}{24 hours } & \multicolumn{2}{|c|}{48 hours } & \multicolumn{2}{|c|}{72 hours } & \multicolumn{2}{|c|}{96 hours } & \multicolumn{2}{|c|}{120 hours } & \\
\hline & $\begin{array}{l}\text { Growth } \\
(\mathrm{mm})\end{array}$ & $\begin{array}{l}\text { PI } \\
(\%)\end{array}$ & $\begin{array}{c}\text { Growth } \\
(\mathrm{mm})\end{array}$ & $\begin{array}{l}\text { PI } \\
(\%)\end{array}$ & $\begin{array}{l}\text { Growth } \\
(\mathrm{mm})\end{array}$ & $\begin{array}{l}\text { PI } \\
(\%)\end{array}$ & $\begin{array}{l}\text { Growth } \\
(\mathrm{mm})\end{array}$ & $\begin{array}{l}\text { PI } \\
(\%)\end{array}$ & $\begin{array}{c}\text { Growth } \\
(\mathrm{mm})\end{array}$ & $\begin{array}{c}\text { PI } \\
(\%)\end{array}$ & \\
\hline $\begin{array}{l}\text { Treatment } \\
1=\text { Phytophthora } \\
\text { colocasiae+Cladosporium } \\
\text { herbarum }\end{array}$ & $\begin{array}{c}11.33 \\
(19.67)^{*}\end{array}$ & 20.00 & $\begin{array}{c}21.00 \\
(27.27)\end{array}$ & 9.35 & $\begin{array}{c}27.50 \\
(31.63)\end{array}$ & 7.30 & $\begin{array}{c}33.50 \\
(35.37)\end{array}$ & 8.64 & $\begin{array}{c}40.17 \\
(39.33)\end{array}$ & 8.37 & 26.70 \\
\hline $\begin{array}{l}\text { Treatment } 2=P . \\
\text { colocasiae }+ \text { Penicillium } \\
\text { citrinum }\end{array}$ & $\begin{array}{c}10.00 \\
(18.43)\end{array}$ & 29.41 & $\begin{array}{c}19.83 \\
(26.44)\end{array}$ & 14.39 & $\begin{array}{c}27.84 \\
(31.85)\end{array}$ & 6.16 & $\begin{array}{c}32.17 \\
(34.55)\end{array}$ & 12.27 & $\begin{array}{c}38.00 \\
(38.06)\end{array}$ & 13.31 & 25.57 \\
\hline $\begin{array}{l}\text { Treatment } 3=P . \\
\text { colocasiae }+ \text { Aspergillus } \\
\text { niger isolate } 1\end{array}$ & $\begin{array}{c}12.83 \\
(20.99)\end{array}$ & 9.41 & $\begin{array}{c}20.83 \\
(27.15)\end{array}$ & 10.07 & $\begin{array}{c}26.33 \\
(30.87)\end{array}$ & 11.24 & $\begin{array}{c}28.67 \\
(32.37)\end{array}$ & 21.82 & $\begin{array}{c}33.50 \\
(35.37)\end{array}$ & 23.57 & 24.43 \\
\hline $\begin{array}{l}\text { Treatment } 4=P . \\
\text { colocasiae }+ \text { Aspergillus } \\
\text { niger isolate } 2\end{array}$ & $\begin{array}{c}12.00 \\
(20.27)\end{array}$ & 15.29 & $\begin{array}{c}19.17 \\
(25.97)\end{array}$ & 17.27 & $\begin{array}{c}24.00 \\
(29.33)\end{array}$ & 19.10 & $\begin{array}{c}29.50 \\
(32.90)\end{array}$ & 19.55 & $\begin{array}{c}30.50 \\
(33.52)\end{array}$ & 30.42 & 23.03 \\
\hline $\begin{array}{l}\text { Treatment } 5=P . \\
\text { colocasiae }+ \text { Penicillium } \\
\text { spp. }\end{array}$ & $\begin{array}{c}12.67 \\
(20.85)\end{array}$ & 10.59 & $\begin{array}{c}19.83 \\
(26.44)\end{array}$ & 14.39 & $\begin{array}{c}24.83 \\
(29.89)\end{array}$ & 16.29 & $\begin{array}{c}30.83 \\
(33.73)\end{array}$ & 15.91 & $\begin{array}{c}38.50 \\
(38.35)\end{array}$ & 12.17 & 25.33 \\
\hline $\begin{array}{l}\text { Treatment } 6=P . \\
\text { colocasiae }+ \text { Mucor } \\
\text { hiemalis }\end{array}$ & $\begin{array}{c}11.17 \\
(19.52)\end{array}$ & 21.18 & $\begin{array}{c}16.83 \\
(24.22)\end{array}$ & 27.34 & $\begin{array}{c}20.33 \\
(26.80)\end{array}$ & 31.46 & $\begin{array}{c}21.67 \\
(27.74)\end{array}$ & 40.91 & $\begin{array}{c}21.67 \\
(27.74)\end{array}$ & 50.57 & 18.60 \\
\hline $\begin{array}{l}\text { Treatment } 7=P . \\
\text { colocasiae }+ \text { Penicillium } \\
\text { oxalicum }\end{array}$ & $\begin{array}{c}13.00 \\
(21.13)\end{array}$ & 8.24 & $\begin{array}{c}19.17 \\
(25.97)\end{array}$ & 17.27 & $\begin{array}{c}25.50 \\
(30.33)\end{array}$ & 14.04 & $\begin{array}{c}30.67 \\
(33.63)\end{array}$ & 16.36 & $\begin{array}{c}30.67 \\
(33.63)\end{array}$ & 30.04 & 23.80 \\
\hline $\begin{array}{l}\text { Treattment } \\
8=\text { Phytophthora } \\
\text { colocasiae(control) }\end{array}$ & \multicolumn{2}{|c|}{14.17} & \multicolumn{2}{|c|}{23.17} & \multicolumn{2}{|c|}{29.67} & \multicolumn{2}{|c|}{36.67} & \multicolumn{2}{|c|}{43.83} & \\
\hline $\operatorname{SEm} \pm$ & \multicolumn{2}{|c|}{0.06} & \multicolumn{2}{|c|}{0.09} & \multicolumn{2}{|c|}{0.12} & \multicolumn{2}{|c|}{0.11} & \multicolumn{2}{|c|}{0.13} & \\
\hline $\mathrm{CD}(p=0.05)$ & \multicolumn{2}{|c|}{0.17} & \multicolumn{2}{|c|}{0.27} & \multicolumn{2}{|c|}{0.36} & \multicolumn{2}{|c|}{0.34} & \multicolumn{2}{|c|}{0.40} & \\
\hline
\end{tabular}

of Phytophthora blight of colocasia caused by Phytophthora colocasiae was positively related to plant age and rainfall. The available literature suggests that generally phylloplane microbial population increases with plant age (Mazen et al., 1986; Dhawan et al., 1995; Zaher et al., 1985; Sharma, 2004). Fungal species dominating the leaf surface in various crop ages differ. In the present study Cladosporium herbarum, Penicillium citrinum, P. oxalicum were found to be dominant on the mature colocasia leaves (180 DAP). This finding is corroborated with the results of Narmala and Mehrotra (1981), Tsuneda and Skoropad (1978) and Ahmed (1986). Rainfall may play two roles in regulating the phylloplane microbial populations. Firstly it may have working effect and secondly rainfall provides the mixture on the leaf surface microflora. However as colocasia leafs are waxy, raindrops cannot accumulate on the leaf surface, therefore washing effect of rainfall might have played major role in occurrence of colocasia phylloplane mycoflora.

3.2. Antagonistic effect of phylloplane fungal isolates against Phytophthora colocasiae Racib. in vitro

Seven phylloplane fungal isolates of colocasia viz., C. herbarum, P. citrinum, A. niger isolate 1, A. niger isolate 2, Penicillium spp., M. hiemalis and P. oxalicum were screened for their inhibitory actions on the growth of Phytophthora colocasiae Racib. the causal agent of colocasia leaf blight by using dual culture plate technique. The effect of all the phylloplane fungi significantly differed at intervals of incubation from that of control. The growth of $P$. colocasiae in the treated plates were observed to progress until they came in contact with the leading edges of the phylloplane fungi, after which it ceased 
to grow and only the phylloplane fungi continued to grow. The $\%$ inhibition of mycelial growth of $P$. colocasiae over control was observed highest by Mucor hiemalis (50.57\%), followed by Aspergillus niger isolate $2(30.42 \%)$, Penicillium oxalicum (30.04\%), and Aspergillus niger isolate 1 (23.57\%). The lowest $\%$ inhibition of the colocasia blight pathogen in vitro was observed in Cladosporium herbarum (8.37\%). Tembhare et al. (2012) reported that phyllosphere fungi showed inhibiting ability against Colletotrichum capsici. M. hiemalis is not known to be an established antagonist against $P$. colocasiae or any other plant pathogens till date. Rudakovet al. (1987) made a study on the relationship between fungi of the wheat phylloplane (pathogens, hyperparasites and saprophytes), their competition and mutual antagonism. In this investigation M. hiemalis was found to have fast growth and over grow the pathogen colony completely five days after inoculation. From the growth pattern in Petri dish it can be assumed that competition for food and/or space may be the mechanism of suppression of $P$. colocasiae by $M$. hiemalis instead of direct antibiosis

\section{Conclusion}

There is a considerable variation in the phylloplane mycoflora of colocasia with respect to plant age under the agro-ecological condition of Medziphema, Nagaland. Mucor hiemalis was observed with highest inhibition $(50.57 \%)$ of radial growth of $P$. colocasiae in vitro. Findings of the present investigation opens up new areas of research in the largely unexplored and dynamic phylloplane of various plants and an avenue for further research on $M$. hiemalis as antagonist against $P$. colocasiae.

\section{References}

Ahmed, M. A., 1986. Behavior of phyllosphere fungi on maize leaves in Egypt. News letter Microbiological Research Centre, Cairo, Egypt 11, 9-16.

Andrews, J.H., Kinkel, L.L., 1986. Colonization dynamics: The island theory. In: Fokkema, N.J., van den Heuvel, J., (Eds.), Microbiology of the phyllosphere, Cambridge University Press, New York, 63-76.

Bainbridge, A., Dickinson, C.H., 1972. Fungicide resistance and population variation in Verticillium fungicola, a pathogen of the button mushroom, Agaricus bisporus. Mycoclogical research 101, 89-96.

Dhawan, S.R., Dhawan, P., 1995. Phyllosphere mycoflora of Parthenium hysterophorus L. World Weeds 2(3-4), 203-210.

Jindal, K.K., Thind, B.S., 1990. Phylloplane microflora of cow pea: dynamics of bacterial and fungal populations. Plant Disease Research 5(1), 17-24.

Mazen, M.B., Abdel Hafez, S.I.J., Shaban, G.M., 1986. Seasonal fluctuations of phyllosphere and phylloplane fungi of Egyptian wheat. Acta Mycologica 21(1), 109115.

Mishra, R.R., Tewari, R.P., 1969. Plant height as a factor in relation to leaf surface mycoflora of Cassia tora. Indian Journal of Microbiology IX 3, 73-76.

Nagamani, A., Kunwar, I.K., Manoharachary, C., 2006. Handbook of soil fungi 6, 120-348.

Narmala, K.L., Mehrotra, R.S., 1981. Phylloplane microflora of Colocasia esculenta L. Schott in relation to Phytophthora colocasiae Racib. Geobios 8(4), 152-156.

Pandey, M.L., Gupta, R.C., 1985. Studies on leaf surface mycoflora of Amaranthus paniculatus grown in Almora hills. Madras Agricultural Journal 72(5), 272-275.

Pandey, R.R., Dwivedi, R.S., 1984. Seasonal incidence of phylloplane mycoflora of guava with reference to fungal pathogens. Acta Botanica Indica 12, 1-8.

Pouono, K., Tuugasala, S., Craswell, E.T., Asher, C.J., O'Sullivan, J.N., 1966. The incidence of taro leaf blight Phytophthora colocasia in relation to rainfall in Western Samoa. Mineral nutrient disorders of root crops in the Pacific. In: Proceedings of a workshop, Nuku'alofa, Kingdom of Tonga, 105-109; ACIAR Proceedings No. 65.

Rudakov, O.L., Tkachev, V.D., Klientova, G.V., Strepenyuk, L.Pn., 1987. Selective effect of fungicides on fungi of the wheat phylloplane. Mikologiya i Fitopatologiya 21(4), 369

Sharma, I., 2004. Phylloplane micro fungi of sugarcane. Indian Journal of Microbiology 44(2), 113-115.

Singh, R.S., 1995. Phyllosphere mycoflora of muskmelon and bottle gourd with their ecological significance. Indian Journal of Mycology and Plant Pathology 25(3), 272-276.

Statistical Handbook of Nagaland, 2011. Directorate of Economics and Statistics, Nagaland, 374.

Tembhare, N.R., Mate, G.D., Gajbhiye, P.R., 2012. Phyllosphere fungi of chilli and antagonism against Colletotrichum capsici. Journal of Plant Disease Sciences 7(1), 45-47.

Tsuneda, A., Skoropad, W.P., 1978. Phylloplane fungal flora of rapeseed. Transactions of the British Mycological Society 70(3), 329-333.

Venedikian, N., Godeas, A.M., 1996. Phyllosphere studies in Pinus taeda L. Pinaceae II. Variation of the amount fungal mycelium and leaf colonization. Physis Secciones 52, 122-123, 19-26.

Zaher, E., Barakat, F.M., Osman, A.R., El Khaleely, M.I., 1986. Role of phyllosphere fungi in antagonism against Ulocladium botrytis Preuss, causing tomato leaf spot in Egypt. Egyptian Journal of Phytopathology 17(1), 1-13. 